\title{
REPORT FROM THE INTERNATIONAL SCIENTIFIC CONFERENCE „NEW LEGISLATION ON THE ADMINISTRATIVE PUNISHMENT"
}

\author{
Ludovít Máčaj, Matúš Mesarčík \\ Comenius University in Bratislava, Faculty of Law
}

On the $10^{\text {th }}$ November, 2017 department of Administrative and Environmental Law of Comenius University in Bratislava, Faculty of Law organized international scientific conference held in the premises of the aforementioned faculty in the context of potential adoption of new legislation of the administrative punishment. The conference represents final outcome of the Department with regard to the project VEGA n. 1/0136/15 named "Legislation concerning Administrative punishment." Participants presented their submissions focusing on a timely and suggestive topic.

The conference was held under the auspices of doc. JUDr. Mária Srebalová, PhD. from the Faculty of Law of Comenius University in Bratislava, who was substituted by JUDr. Matej Horvat, PhD. due to her absence. The event was opened by the speech delivered by JUDr. Matej Horvat who welcomed honored guests and especially appreciated the internationality of the platform.

The introductory lecture was given by prof. JUDr. Katarína Tóthová, DrSc., who outlined the general aspects of the administrative punishment and specifically analyzed the institute of the objective deadline with regard to settling of administrative offenses. Then the floor was taken by JUDr. Stanislav Kadečka, PhD. from the Faculty of Law of Masaryk University in Brno. Dr. Kadečka highlighted application problems from the Czech Republic in the context of circumstances excluding the illegality and the extinction of liability for administrative offenses. The opening session of the conference was concluded by JUDr. Tibor Seman, PhD. from the Law Faculty of Pavol Jozef Šafárik University in Košice, who evaluated selected institutes of the future legal regulation of administrative offenses and mentioned selected semantic and linguistic issues concerning the potential legislation.

Second session of the conference focused on aspects of the administrative punishment in the area of the Environmental law. The session was opened by Mgr. Martin Dufala, PhD., pointing out issues of a municipal waste management and legislation and categorization of related administrative offenses. Mgr. Ludovít Máčaj analyzed the level of the current legislation on administrative punishment for unauthorized soil management and protection. At the end of this section concerning environmental law Mgr. Lucia Čerňanová dealt with a very current and interesting topic of environmental burdens, which she also approached taking into account cases from practice.

The afternoon program was opened by the Head of the Department of Administrative and Environmental Law of the Faculty of Law of the Comenius University in Bratislava, prof. JUDr. Marián Vrabko, CSc. with his contribution about the possibilities of developing sanctions in the administrative punishment and the prospects for future legislation. The session continued by the submission delivered by doc. Mgr. Ján Škrobák, PhD., who presented his considerations de lege ferenda regarding the principle of material truth and the amount of fines in the administrative punishment. The conclusion of the section was provided by Mgr. Marianna Džačková with her presentation focusing on application problems in practice related to the application of the principles of criminal law in proceedings on administrative offenses sanctioned by the Council for Broadcasting and Retransmission. 
The final session was opened by doc. JUDr. Juraj Vačok, $\mathrm{PhD}$. with a unique lecture on the material and political circumstances and the methodology of the approach to the new legislation on the administrative punishment. Subsequently, Mgr. Ján Brož from the Faculty of Law at Masaryk University in Brno presented his submission on the criteria for the imposition of the administrative penalties. Mgr. Matúš Mesarčík, LL.M. delivered a few considerations on the effectiveness and suitability of administrative sanctions in the area of personal data protection, emphasizing the debate on other sanctions than administrative fines and criminal sanctions. The last section of the conference was concluded by JUDr. Matej Horvat, PhD. with his interpretation of the principle of binding law in the new law on administrative punishment.

The conference has been enormously enriching in terms of academic exchange of views and views with high relevance to potential future legislation governing the issue. Hopefully, events of a similar quality will be held at the Faculty of Law of Comenius University in Bratislava in the near future.

\section{Contact information:}

Mgr. Ludovít Máčaj

ludovit.macaj@flaw.uniba.sk

Comenius University in Bratislava, Faculty of Law

Mgr. Matúš Mesarčík, LL.M.

matus.mesarcik@flaw.uniba.sk

Comenius University in Bratislava, Faculty of Law

Šafárikovo nám. č. 6

P. O. BOX 313

81000 Bratislava

Slovak Republic 